Developments in British Politics 4 
Also available from Macmillan Education

Peter Hall, Jack Hayward and Howard Machin (eds) DEVELOPMENTS IN FRENGH POLITICS

Gillian Peele, Christopher Bailey and Bruce Cain (eds) DEVELOPMENTS IN AMERICAN POLITICS

Gordon Smith, William E. Paterson, Peter H. Merkl and Stephen Padgett (eds)

DEVELOPMENTS IN GERMAN POLITICS

Stephen White, Judy Batt and Paul G. Lewis (eds) DEVELOPMENTS IN EAST EUROPEAN POLITICS

Stephen White, Alex Pravda and Zvi Gitelman (eds) DEVELOPMENTS IN SOVIET AND POST-SOVIET POLITICS

\author{
Forthcoming \\ Patrick Dunleavy \\ ANALYSING BRITISH POLITICS
}




\title{
Developments in British Politics 4
}

\author{
Edited by \\ Patrick Dunleavy \\ Andrew Gamble \\ Ian Holliday \\ Gillian Peele
}


(C) Editorial matter and selection (C) Patrick Dunleavy, Andrew Gamble, Ian Holliday and Gillian Peele 1993

Softcover reprint of the hardcover 1st edition 1993 978-0-333-58014-1

Individual chapters (in order) (C) Gillian Peele, Neill Nugent, Andrew Gamble, Ivor Crewe, Patrick Dunleavy, Gavin Drewry, Keith Dowding, Desmond King, Stephen Wilks, Chris Pierson, John McCormick, David Sanders, Ian Holliday, John Solomos and Les Back, David Marsh, David Beetham 1993

All rights reserved. No reproduction, copy or transmission of this publication may be made without written permission.

No paragraph of this publication may be reproduced, copied or transmitted save with written permission or in accordance with the provisions of the Copyright, Designs and Patents Act 1988, or under the terms of any licence permitting limited copying issued by the Copyright Licensing Agency, 90 Tottenham Court Road, London WIP 9HE.

Any person who does any unauthorised act in relation to this publication may be liable to criminal prosecution and civil claims for damages.

This book is a direct replacement for

Developments in British Politics (1983)

Developments in British Politics 2 (1986)

Developments in British Politics 3 (1990)

First published 1993 by

THE MACMILLAN PRESS LTD

Houndmills, Basingstoke, Hampshire RG21 2XS

and London

Companies and representatives

throughout the world

ISBN 978-0-333-58014-1

ISBN 978-1-349-22802-7 (eBook)

DOI 10.1007/978-1-349-22802-7

A catalogue record for this book is available from the British Library.

Copy-edited and typeset by Povey-Edmondson

Okehampton and Rochdale, England 


\section{Contents}

List of Contributors $\quad \mathrm{x}$

Preface xii

1 Introduction: Stability, Crisis or Decline?

Patrick Dunleavy

Super-stability

Latent Crisis

Managed Decline

Conclusion: Future Prospects

\section{Part ONe: The Political System}

2 The Constitution Gillian Peele 19

One-party Dominance 21

The Erosion of Traditional Constitutional

Theories 24

Pressure Groups for Constitutional Reform 27

Electoral Reform $\quad 30$

A Scottish Parliament 33

Regional Reform 34

The House of Lords $\quad 36$

The Monarchy 38

$\begin{array}{ll}\text { Conclusion } & 39\end{array}$

3 The European Dimension Neill Nugent 40

The Maastricht Treaty 41

The Impact of the EC on British Political Processes 54

The Policy Impact of the EC 60

Future Prospects 66

4 Territorial Politics Andrew Gamble 69

The 1992 General Election $\quad 69$

Territorial Management $\quad 71$

$\begin{array}{ll}\text { National Identity } & 73\end{array}$ 
$\begin{array}{ll}\text { Scotland } & 75\end{array}$

Wales $\quad 81$

Northern Ireland $\quad 85$

$\begin{array}{ll}\text { Conclusion } & 90\end{array}$

5 Voting and the Electorate Ivor Crewe 92

Interpreting Election Results $\quad 93$

Trends in Partisanship $\quad 98$

Short-term Influences on the Vote 107

The Operation of the Electoral System 116

6 The Political Parties Patrick Dunleavy 123

The Conservative Party 124

The Labour Party 135

The Liberal Democrats 146

Conclusion $\quad 152$

7 Parliament Gavin Drewry 154

Parliament, the Party System and the Prime
Minister

Scrutiny of Government: Recent Trends 157

The Select Committees Re-established 161

Parliament, the Citizen's Charter and the Next

Steps Agencies 166

The House of Lords $\quad 168$

Parliament and the EC $\quad 169$

Parliament in the 1990s 172

8 Government at the Centre Keith Dowding 175

The Citizen's Charter 177

$\begin{array}{ll}\text { The Core Executive } & 178\end{array}$

Open Government 183

Private Advisers 183

Departmental Power $\quad 185$

Policy Networks 186

The Next Steps Reforms $\quad 187$

Next Steps and Ministerial Responsibility 189

The EC 191

Conclusion 193 


\section{Government Beyond Whitehall}

Desmond King

The Crisis of Local Government Finances: From

Poll Tax to Council Tax

196

The Formal and Informal Local Government

Systems

203

The Study of Local Government

215

\section{Part Two: Public Policy}

10 Economic Policy Stephen Wilks

221

Macro- and Micro-economic Policy: the Great

Divide

Macro-economic Policy: the Record

225

Economic Policy and Europe

227

'Supply-side' Policy in Context

232

From 'Pure-market' to 'Social-market'?

238

Prospects for an Industrial Policy

240

Supply-side Policy From the Bottom of the Cliff

244

Conclusion

11 Social Policy Chris Pierson

The 1990s: 'A New Era for Social Policy'?

Continuity and Change in British Social Policy: the 1990s

The Continuing Failures of British Social Policy

Policy Challenges in the 1990s

Conclusion: Towards a New Welfare Consensus?

12 Environmental Politics John McCormick

The Policy Debate

Policy Developments

271

Britain and the EC

273

The International Dimension

275

The Changing Environmental Lobby

Green Consumerism and Green Politics

The Changing Place of Environmental Policy 
13 Foreign and Defence Policy David Sanders

The End of the Cold War

UK Defence and Foreign Policy Strategy in the 1990s: the Strategic Options

The Foreign Policy-making Process

298

Explaining Britain's Foreign Policy Strategy

301

Problems for the Mid-1990s

\section{Part Three: GurRent IsSUes}

\section{Organised Interests After Thatcher} Ian Holliday

The Strange Death of Liberal Corporatism

Thatcherism's Critique of Liberal Corporatism

Organised Interests Under Thatcher

Trade Unions After Thatcher

Organised Interests in the 1990s

Conclusion

\section{Migration and the Politics of Race}

John Solomos and Les Back

Recent Trends in Europe

Is Britain the Exception?

Political Mobilisation by Ethnic Minorities

Conclusion: the Future for Multiculturalism

16 The Media and Politics David Marsh

The Role of the Media

Views of Democracy and Views of the Media

Examining the Media's Role

The Media and Democracy - Revisited

\section{Part Four: Theorising British POLITICS}

\section{Political Theory and British Politics}

\section{David Beetham}


Democracy: Majority Rule, Pluralism or Citizens' Rights?

Representation: Proportional or Disproportional? 364 Conclusion: Legitimacy Deficit or Legitimation Crisis?

Guide to Further Reading 


\section{List of Contributors}

Les Back is Lecturer in the Department of Cultural Studies, University of Birmingham. He has published a number of articles on race, youth and identity, and on the politics of race and social change.

David Beetham is Professor of Politics at the University of Leeds and consultant to the Rowntree-funded Democratic Audit of the UK. Among his works on social and political theory are Bureaucracy and The Legitimation of Power.

Ivor Crewe is Professor of Government at the University of Essex. Recent publications include The British Electorate 19631987 (co-authored) and Political Communications: The General Election Campaign of 1992 (co-edited).

Keith Dowding is Lecturer in Politics at Brunel, the University of West London. Recent publications include Rational Choice and Political Power and The Civil Service.

Gavin Drewry is Professor of Public Administration and Head of the Department of Social Policy and Social Science at Royal Holloway University of London. Recent publications include The New Select Committees (second edition) (editor and principal author) and The Civil Service Today (second edition) (co-author).

Patrick Dunleavy is Professor of Government at the London School of Economics and Political Science. Recent publications include Democracy, Bureaucracy and Public Choice and Replaying the 1992 General Election (co-authored).

Andrew Gamble is Professor of Politics at the University of Sheffield. Recent bookss include The Free Economy and the Strong State and Britain in Decline (third edition).

Ian Holliday is Lecturer in the Department of Government, University of Manchester. Recent publications include The NHS Transformed: A Guide to the Health Reforms, and a series of articles on British politics and policy.

Desmond King is Fellow and Tutor in Politics at St John's College, Oxford. Recent publications include The State and the City (co-authored). 
John McCormick is Assistant Professor of Political Science at Indiana University-Purdue University at Indianapolis (IUPUI). Recent publications include The Global Environmental Movement and British Politics and the Environment.

David Marsh is Professor in the Department of Government, University of Strathclyde. Recent publications include The New Politics of British Trade Unionism and Implementing Thatcherism: Audit of an Era (co-edited).

Neill Nugent is Reader in Politics at the Manchester Metropolitan University. Recent publications include The Government and Politics of the European Community (second edition) and articles on the changing nature of the European Community.

Gillian Peele is Fellow and Tutor in Politics at Lady Margaret Hall, Oxford. She is co-editor of Developments in American Politics and author of numerous books and articles on British and American politics.

Chris Pierson is Senior Lecturer in the Department of Political Studies, University of Stirling. Recent books include Beyond the Welfare State? and Market Socialism.

David Sanders is Reader and Head of the Department of Government, University of Essex. Recent publications include Lawmaking and Co-operation in International Politics and Losing an Empire, Finding a Role.

John Solomos is Reader in Public Policy in the Department of Politics and Sociology, Birkbeck College. Recent publications include Race and Racism in Britain (second edition) and Racism and Migration in Western Europe (co-edited).

Stephen Wilks is Professor of Politics at the University of Exeter. Recent publications include 'Science, Technology and the Large Corporation', in Government and Opposition and The Promotion and Regulation of Industry in Fapan. 


\section{Preface}

This is the fourth Developments in British Politics volume. All the chapters are once again new, with a new set of contributors. The editorial team has remained the same as Developments 3 except that Ian Holliday has joined us and has quickly proved himself indispensable.

As in previous volumes individual authors were asked both to analyse recent developments in policy and events, and to review some of the crucial theories and models available for interpreting them. All authors were asked to concentrate in their chapters on the period since the downfall of Margaret Thatcher and the ending of the Cold War. We have continued the practice begun in Developments 3 of including an Introduction which surveys major perspectives for understanding the present condition of British politics. This is followed by individual chapters on the political system, public policy, and current issues, and a final chapter, this time written by David Beetham, which provides reflections on some major themes in the study of political theory and British politics - the nature of sovereignty, the meaning of democracy, and the character of political representation. Two innovations this year are separate chapters on the Constitution and Territorial Politics. We have also chosen three new topics for the current issues section - organised interests after Thatcher, migration and the politics of race, and the media and politics.

We would like to thank our authors for cooperating with what is always a tight publishing schedule. Our publisher, Steven Kennedy, has once again provided first-class support and encouragement. We are very grateful to him. Suggestions for improving Developments in the future, as well as comments on - and criticisms of - the present volume are very welcome.

Patrick Dunleavy Andrew Gamble

Ian Holliday

Gillian Peele 